\title{
Korelasi Motivasi Kerja Terhadap Kinerja Sumber Daya Insani Di Politeknik Al Islam Bandung Tahun 2017
}

\author{
Dian Nuramdiani ${ }^{1}$, Nieke Resmiati ${ }^{2}$, Yoppie Kaerunnisa ${ }^{3}$ \\ ${ }^{1}$ Politeknik Al Islam Bandung \\ Email: nenkdee@gmail.com
}

\begin{abstract}
ABSTRAK
Sebagai salah satu lembaga penyelenggara pendidikan tinggi, Politeknik Al Islam Bandung dituntut untuk dapat memberikan pelayanan optimal dalam menghasilkan lulusan yang berkualitas. Sebagai salah satu living organism yang memiliki peran utama dalam mencapai tujuan suatu instansi atau lembaga pendidikan tinggi, maka Politeknik Al Islam Bandung membutuhkan sumber daya insani yang bermutu dan profesional. Penelitian ini dilakukan untuk mengetahui gambaran motivasi kerja sumber daya insani di Politeknik Al Islam Bandung, serta mengetahui korelasi antara motivasi kerja yang dimiliki sumber daya insani terhadap kinerja yang dihasilkan. Penelitian dilakukan terhadap 37 responden yang terdiri dari tendik (dosen) dan non tendik. Hasil penelitian menunjukkan bahwa sekitar 83,8\% sumber daya insani Politeknik Al Islam Bandung memiliki motivasi kerja yang tinggi, dengan rata-rata nilai 120,4. Korelasi antara motivasi kerja dengan kinerja yang dihasilkan termasuk kategori kuat yang dibuktikan dengan nilai koefisien korelasi sebesar $r=0,695$. Uji signifikansi pun dilakukan dengan taraf signifikansi 5\% untuk membuktikan adanya hubungan positif dan signifikan antara motivasi kerja sumber daya insani terhadap kinerja yang dihasilkan. Hasil menunjukkan bahwa $t_{\text {hitung }}$ lebih besar dari $t_{\text {tabel }}$ yaitu 5,72 > 1,689, yang artinya penelitian ini berhasil membuktikan bahwa adanya hubungan yang kuat antara motivasi kerja dengan kinerja.
\end{abstract}

Kata kunci: Sumber Daya Insani, Motivasi Kerja, Kinerja

\begin{abstract}
As one of higher education institutions, Politeknik Al Islam Bandung should be able to give optimal services in producing qualified graduates. As one living organisms that has a major role in achieving goals of higher education institutions, the Politeknik Al Islam Bandung requires qualified and profesional human resources. The aim of this study is to find out the information about human resources in Politeknik Al Islam Bandung, and also to know the correlation between work motivation owned by its human resources and resulted performance. The study was conducted on 37 respondents consisting of lecturers and staffs of Politeknik Al Islam Bandung. The results show that about $83.8 \%$ of human resources of Politeknik Al Islam Bandung have high motivation, with an average of 120,4. The correlation between work motivation and performance conducted by them belongs to strong category, which is proved by $\boldsymbol{r}$ coefficient value of 0,695. The significance test was carried out with a significance level of 5\% to prove positive and significant relationships between the work motivation and performance of the human resources. The results show that $t_{\text {count }}$ is greater than $t_{\text {table }}(5.72>1.689)$. It means that this study has succesfully proved that there is a strong relationship between work motivation and performance.
\end{abstract}

Keywords: human resources, work motivation, performance 


\section{PENDAHULUAN}

Undang-Undang No. 12 tahun 2012 tentang Pendidikan Tinggi, menyatakan bahwa pendidikan adalah usaha sadar dan terencana untuk mewujudkan suasana belajar dan proses pembelajaran agar peserta didik secara aktif mengembangkan potensi dirinya untuk memiliki kekuatan spiritual keagamaan, pengendalian diri, kepribadian, kecerdasan, akhlak mulia, serta keterampilan yang diperlukan dirinya, masyarakat, bangsa, dan negara.

Sebagai salah satu lembaga penyelenggara pendidikan tinggi, Politeknik Al Islam Bandung sudah seharusnya memiliki fungsi untuk turut serta mengembangkan kemampuan dan membentuk watak serta peradaban bangsa yang bermartabat dalam rangka mencerdaskan kehidupan bangsa; mengembangkan sivitas akademika yang inovatif, responsif, kreatif, terampil, berdaya saing, dan kooperatif melalui pelaksanaan Tridharma; dan mengembangkan Ilmu Pengetahuan dan Teknologi dengan memperhatikan dan menerapkan nilai humaniora.

Untuk memungkinkan berfungsinya suatu pendidikan tinggi maka diperlukan sumber daya yang bermutu dan profesional baik di bidang akademis, teknis, maupun di bidang administrasi dan keuangan guna melaksanakan penyelenggaraan pendidikan yang optimal. Sumber Daya Insani (SDI) mempunyai pengaruh besar dalam mencapai tujuan suatu Instansi atau Lembaga Pendidikan Tinggi, karena sumber daya insani inilah yang merupakan living organism sebagai pemeran utama dalam menjalankan seluruh proses kegiatan pelayanan pendidikan.

Sumber daya insani akan dapat bekerja dengan baik dalam mencapai tujuan tertentu apabila setiap individunya mempunyai minat dan semangat terhadap suatu pekerjaan. Minat dan semangat tersebut merupakan salah satu dorongan atau motivasi yang menjadi kunci kebutuhan seluruh sumber daya insani dalam melakukan seluruh kegiatan pelayanan di suatu lembaga perguruan tinggi. Dalam konteks pekerjaan, motivasi merupakan salah satu faktor penting dalam mendorong sumber daya insani untuk bekerja. Pada umumnya setiap lembaga pendidikan tinggi mempunyai harapan yang besar agar seluruh sumber daya insani yang terlibat dalam proses penyelenggaraan pendidikan dapat memberikan kinerja yang baik dan efektif dalam melakukan tanggung jawab terhadap pekerjaannya.

Kinerja sumber daya insani merupakan hasil kerja yang dicapai seseorang dalam melaksanakan tugas-tugas yang dibebankan kepadanya, meliputi kualitas dan kuantitas output serta keandalan dalam bekerja. Namun berdasarkan data dari bagian kepegawaian Politeknik Al Islam Bandung, tercatat masih ada beberapa kinerja sumber daya insani yang belum sesuai dengan harapan. Salah satu bukti yang menyatakan hal tersebut adalah dari segi kehadiran beberapa pegawai yang masih tidak sesuai dengan ketentuan yang berlaku. Tercatat untuk bulan Januari sampai dengan Juni 2017 rata-rata jam kerja pegawai yang memenuhi ketentuan jam kerja dalam seminggu hanya sekitar 50\%. Sehingga dengan demikian betapa pentingnya motivasi kerja dalam meningkatkan kinerja sumber daya insani agar dapat tercapainya penyelenggaraan pendidikan tinggi yang baik.

Berdasarkan uraian di atas penelitian ini dilakukan untuk mengetahui gambaran motivasi kerja sumber daya insani di Politeknik Al Islam Bandung, dan untuk mengetahui bagaimana hubungannya antara motivasi kerja terhadap kinerja yang dihasilkan. 


\section{METODE PENELITIAN}

Penelitian ini dilakukan di Politeknik Al Islam Bandung, terhitung dari bulan September s/d Desember 2017. Metode yang digunakan adalah jenis penelitian kuantitatif dengan pendekatan deskriptif analitik. Pengumpulan data dilakukan dengan teknik menyebarkan angket / kuisioner ke 37 orang pegawai Politeknik Al Islam Bandung yang terdiri dari dosen dan staff.

Kuisioner yang digunakan berupa kuesioner tipe pilihan dengan menggunakan skala Likert dengan lima alternatif jawaban, yakni sangat setuju (SS), setuju (S), kurang setuju (KS), tidak setuju (TS), dan sangat tidak setuju (STS). Kuisioner terdiri dari 54 pertanyaan yang di dalamnya terdiri dari indikator variabel motivasi kerja sebanyak 30 pertanyaan yang mencakup faktor instrinsik (Prestasi, Pengakuan, Tanggung jawab, Kesempatan untuk maju, Pekerjaan itu sendiri), dan faktor ekstrinsik (Kondisi kerja fisik, Hubungan antar pribadi, Kebijakan dan Administrasi, Pengawasan, Gaji/ upah, Kesehatan dan keselamatan kerja), dan indikator variabel kinerja sumber daya insani sebanyak 24 pertanyaan yang mencakup Loyalitas, Semangat kerja, Kerjasama, Prakarsa, Tanggung jawab, Pencapaian target.

Data yang diperoleh diolah dengan metode statistika sederhana dengan dilakukannya uji regresi dan uji korelasi produk moment untuk mengetahui kekuatan hubungan antara kedua variabel. Selanjutnya dilakukan pula perhitungan koefisien determinasi yang dapat menjelaskan besarnya pengaruh nilai suatu variabel terhadap naik turunnya (variasi) nilai variabel lainnya.

\section{HASIL DAN PEMBAHASAN}

Data variabel motivasi kerja sumber daya insani diperoleh melalui kuesioner variabel motivasi kerja dengan 30 butir pernyataan dan jumlah responden 37 orang. Berdasarkan data yang diolah menggunakan program Microsoft Excel maka diperoleh jumlah skor tertinggi sebesar 145 dan jumlah skor terendah sebesar 92. Hasil analisis menunjukkan rata-rata (mean) sebesar 120,4, median 119, modus 118,7 dan standar deviasi sebesar 11,69.

Selanjutnya penentuan kecenderungan variabel dilakukan untuk kemudian mencari standar deviasi ideal (SDi). Berdasarkan acuan norma, mean ideal variabel motivasi kerja dalam penelitian ini adalah 90 dan standar deviasi ideal adalah 20. Tabel distribusi kecenderungan variabel motivasi kerja sumber daya insani di Politeknik Al Islam ditunjukan pada tabel sebagai berikut:

Tabel 1. Distribusi Kategori Variabel Motivasi Kerja

\begin{tabular}{|c|c|c|c|c|}
\hline \multirow{2}{*}{ No. } & \multirow{2}{*}{ Skor } & \multicolumn{2}{|c|}{ Jumlah } & \multirow{2}{*}{ Kategori } \\
\cline { 3 - 4 } & & Frekuensi & $\%$ & Tinggi \\
\hline 1 & $\geq 110$ & 31 & $83,8 \%$ & Sedang \\
\hline 2 & $70-110$ & 6 & $16,2 \%$ & Rendah \\
\hline 3 & $\leq 70$ & 0 & $0 \%$ & . \\
\hline
\end{tabular}

Lain hal dengan data variabel kinerja sumber daya insani yang diperoleh melalui kuesioner variabel kinerja dengan 24 butir pernyataan dan jumlah responden yang sama. Berdasarkan data yang diolah menggunakan program Microsoft Excel maka diperoleh jumlah skor tertinggi sebesar 120 dan jumlah skor terendah sebesar 78. Hasil analisis menunjukkan ratarata (mean) sebesar 99,3, median 98,125, modus 94,3 dan standar deviasi sebesar 10,016.

Dari perhitungan dengan cara yang sama dengan variable motivasi kerja, maka diperoleh 3 kategori distribusi kecenderungan seperti dalam Tabel 2. berikut: 
Tabel 2. Distribusi Kategori Variabel Kinerja

\begin{tabular}{|c|c|c|c|c|}
\hline \multirow{2}{*}{ No. } & \multirow{2}{*}{ Skor } & \multicolumn{2}{|c|}{ Jumlah } & \multirow{2}{*}{ Kategori } \\
\cline { 3 - 4 } & & Frekuensi & \% & \\
\hline 1 & $\geq 88$ & 32 & $86,5 \%$ & Tinggi \\
\hline 2 & $56-88$ & 5 & $13,5 \%$ & Sedang \\
\hline 3 & $\leq 56$ & 0 & $0 \%$ & Rendah \\
\hline
\end{tabular}

Analisis regresi merupakan salah satu analisis yang bertujuan untuk mengetahui pengaruh suatu variabel terhadap variabel lain. Dalam hal ini analisis regresi digunakan untuk menentukan sifat -sifat dan kekuatan hubungan antara motivasi kerja dan kinerja sumber daya insani di Politeknik Al Islam Bandung, serta memprediksi nilai dari suatu variabel yang belum diketahui. Berdasarkan hasil analisis regresi, maka persamaan garis regresi antar motivasi kerja dan kinerja dapat dinyatakan sebagai berikut:

$$
Y=25,39+0,614 X
$$

Persamaan tersebut menunjukkan bahwa nilai koefisien $\mathrm{X}$ sebesar 0,614 yang berarti bahwa jika nilai motivasi kerja $(\mathrm{X})$ meningkat 1 poin maka kinerja $(\mathrm{Y})$ akan meningkat 0,614 poin. Atau dengan kata lain motivasi kerja mempunyai pengaruh positif (koefisien regresi $(b)=$ $0,614)$ terhadap kinerja sumber daya insani, artinya jika semakin tinggi motivasi kerja yang dimiliki sumber daya insani Politeknik Al Islam Bandung maka akan semakin baik atau tinggi kinerja yang dihasilkan. Tentu saja dengan asumsi faktor-faktor lain yang tidak diteliti dalam penelitian ini diabaikan. Sedangkan nilai konstanta adalah sebesar 25,39, artinya nilai tersebut merupkan nilai minimal jika sumber daya insani tidak memiliki motivasi kerja, maka kinerja sumber daya insani adalah sebesar 25,39 dengan asumsi variabel-variabel lain yang dapat mempengaruhi dianggap tetap.

Berdasarkan analisis Regresi dari variabel motivasi kerja terhadap kinerja sumber daya insani di Politeknik Al Islam Bandung dapat diketahui bahwa terdapat hubungan positif antara kedua variabel. Sebab, dua variabel dikatakan berkolerasi apabila perubahan pada variabel yang satu akan diikuti perubahan pada variabel yang lain.

Rumus yang dipergunakan untuk menghitung korelasi antar variabel adalah Koefisien Korelasi Product Moment. Dan diperoleh nilai koefisien korelasi antara motivasi kerja dan kinerja sumber daya insani di Politeknik Al Islam Bandung sebesar 0,695. Nilai koefisien tersebut menunjukkan bahwa motivasi kerja dari sumber daya insani di Politeknik Al Islam Bandung dan kinerja yang dihasilkan memiliki hubungan yang kuat.

Selanjutnya pengujian koefisien penentu (KP) atau koefisien determinasi (R) dilakukan yang bertujuan untuk mengetahui tingkat ketepatan yang paling baik dalam analisis regresi dan korelasi. KP menjelaskan seberapa besar pengaruh nilai suatu variabel (variabel X) terhadap naik turunnya (variasi) nilai variabel lainnya (variabel Y).

Hasil analisis diperoleh nilai $R^{2}$ sebesar 0,484 atau sama dengan 48,4\%. Hasil ini menginformasikan bahwa kinerja sumber daya insani di Politeknik Al Islam Bandung dapat dijelaskan oleh variabel motivasi kerja sebesar 48,4\%, sedangkan sisanya sebesar 51,65\% dijelaskan oleh variabel lain yang tidak diteliti. Atau dengan kata lain motivasi kerja memberikan kontribusi terhadap kinerja sumber daya insani Politeknik Al Islam Bandung sebesar $48,35 \%$, dan sisanya $51,65 \%$ ditentukan oleh variabel lain. 
Sebagaimana yang sudah dibahas dalam kajian pustaka mengenai motivasi kerja, bahwa motivasi kerja adalah penggerak atau pendorong dalam diri seseorang untuk mau berperilaku dan bekerja dengan giat dan sesuai dengan tugas dan kewajiban yang diberikan kepadanya, maka motivasi kerja akan bermanfaat sebagai pendorong bagi seseorang agar berusaha mencapai kinerja sesuai tugas yang diberikan. Dalam arti lain bahwa setiap sumber daya insani mempunyai energi potensial. Bagaimana energi digunakan tergantung pada kekuatan dorongan yang dimiliki seseorang dan situasi serta peluang yang tersedia.

Sumber daya insani adalah objek sekaligus subjek dari perubahan, karena sumber daya insanilah yang membuat proses transformasi input-output menjadi mungkin. Sebagaimana yang diungkapkan Sedarmayanti (2007), sumber daya insani merupakan faktor yang paling menentukan dalam setiap organisasi, karena disamping sumber daya insani sebagai salah satu unsur kekuatan daya saing bangsa, sumber daya insani bahkan sebagai penentu utama.

Sumber Daya Insani (SDI) mempunyai pengaruh besar dalam mencapai tujuan suatu Instansi atau Lembaga Pendidikan Tinggi, karena sumber daya insani inilah yang merupakan living organism sebagai pemeran utama dalam menjalankan seluruh proses kegiatan pelayanan pendidikan. Sumber daya insani akan dapat bekerja dengan baik dalam mencapai tujuan tertentu apabila setiap individunya mempunyai minat dan semangat terhadap suatu pekerjaan. Minat dan semangat tersebut merupakan salah satu dorongan atau motivasi yang menjadi kunci kebutuhan seluruh sumber daya insani dalam melakukan seluruh kegiatan pelayanan di suatu lembaga perguruan tinggi. Sumber daya insani yang memiliki motivasi tinggi diharapkan dapat bekerja secara maksimal dan berusaha untuk memberikan yang terbaik yang dapat dilakukan karena merupakan tuntutan profesinya. Jika motivasi kerja sumber daya insani maksimal maka diharapkan kinerja yang dihasilkannya pun akan maksimal.

\section{KESIMPULAN}

Rata-rata motivasi kerja yang dimiliki sumber daya insani di Politeknik Al Islam Bandung termasuk kategori tinggi, dengan rincian: $83,8 \%$ termasuk kategori tinggi, 16,2\% termasuk kategori sedang, dan tidak satupun dari sumber daya insani di Politeknik Al Islam Bandung yang termasuk kategori rendah.

Terdapat hubungan positif dan signifikan antara motivasi kerja dengan kinerja sumber daya insani Politeknik Al Islam Bandung, yang ditunjukkan oleh nilai koefisien korelasi dengan kategori kuat sebesar 0,695 . Hubungan tersebut mengindikasikan bahwa semakin tinggi motivasi kerja yang dimiliki sumber daya insani, maka akan semakin tinggi pula kinerja yang dihasilkan.

\section{UCAPAN TERIMA KASIH}

Penulis mengucapkan terima kasih kepada Politeknik Al Islam Bandung yang sudah mendanai penelitian ini melalui program Penelitian Dosen Pemula. Penulis juga mengucapkan terimakasih kepada civitas akademika Politeknik Al Islam Bandung atas dukungan dan partisipasinya dalam penelitian ini. 


\section{DAFTAR RUJUKAN}

Hanggraeni, D. (2011). Perilaku Organisasi. Jakarta: Fakultas Ekonomi Universitas Indonesia.

Hasibuan, M. (2007). Organisasi dan Motivasi. Jakarta: Bumi Aksara.

Mangkunegara, A. P. (2013). Manajemen Sumber Daya Manusia Perusahaan. Bandung: Remaja Rosda Karya.

Miranda. (2011). Audit SDM. Jakarta: Universitas Terbuka.

Notoatmojo, S. (2009). Pengembangan Sumber Daya Manusia. Jakarta: Rineka Cipta.

Sedarmayanti. (2007). Manajemen Sumber Daya Manusia. Bandung: Refika Aditama.

Siagian, S. P. (2014). Manajemen Sumber Daya Manusia. Jakarta: Bumi Aksara.

Sugiyono. (2013). Metode Penelitian Bisnis. Bandung: Alfabeta.

Suwardi, J. U. (2011). Pengaruh Motivasi Kerja, Kepuasan Kerja, dan Komitmen Organisasional terhadap Kinerja Pegawai (studi pada pegawai Setda Kabupaten Pati). Analisis Manajemen.

Tanjung, H. (2003). Manajemen Motivasi. Jakarta: PT Grasindo.

Wibowo. (2013). Manajemen Kinerja. Jakarta: Raja Grafindo. 